\title{
The effect of sedation during transoesophageal echocardiography on heart rate variability: a comparison of hypnotic sedation with medical sedation
}

\author{
Yuksel Dogan ${ }^{1}$, Gulay A. Eren², Evrım Tulubas², Vecihi Oduncu' ${ }^{1}$, Alparslan Sahin ${ }^{1}$, Serkan Ciftci ${ }^{1}$ \\ 1Department of Cardiology, Bahçeşehir Medical University, Fatih Medical Park Hospital, Istanbul, Turkey \\ ${ }^{2}$ Department of Anaesthesiology and Intensive Care, Bakirkoy Dr. Sadi Konuk Education and Research Hospital, Istanbul, Turkey
}

\begin{abstract}
A bstract
Background: There is no ideal sedation technique that can be used during transoesophageal echocardiography (TEE), and the data concerning the effects of available sedation techniques on heart rate variability (HRV) are limited.

Aim: To compare the effects of sedation through hypnotherapy with medical sedation achieved by midazolam on HRV.

Methods: We recruited 76 patients with an indication of TEE; the age range was 18-83 years. In Group T there were 26 patients who had the procedure under topical pharyngeal anaesthesia, in Group D there were 23 patients who received midazolam, and in Group H there were 27 patients receiving hypnosis. All patients had an IV access; throughout the procedure heart rate, rhythm electrocardiography, and peripheric $\mathrm{O}_{2}$ saturation were monitored with a non-invasive monitor, and blood pressure measurements were taken every 3 min. Rhythm Holter recordings were obtained from all patients and TEE was performed.

Results: When time domain parameters for HRV were compared in all three groups, the hypnosis group had significant increases in pNN50 and RMSSD compared to Groups D and T $(p<0.05)$. As concerns frequency domain parameters, there were no significant differences between groups where low frequency (LF) was decreased in hypnosis group and high frequency $(\mathrm{HF})$ was increased $(\mathrm{p}>0.05)$. However, LF/HF was decreased statistically significantly $(p<0.05)$ when compared with the midazolam group.

Conclusions: Contrary to standard sedation in TEE patients, when hypnosis is used autonomic cardiac tone is modified to a significant extent. Hypnotic sedation achieves this by increasing the parasympathetic activity, decreasing the sympathetic activity, and changing the sympathovagal interaction balance.
\end{abstract}

Key words: transoesophageal echocardiography, heart rate variability, hypnotic sedation, midazolam

Kardiol Pol 2016; 74, 6: 591-597

\section{INTRODUCTION}

Transoesophageal echocardiography (TEE) is a diagnostic test utilised when conventional transthoracic echocardiography (TTE) does not yield sufficient information in patients with cardiovascular problems. Contrary to TTE, TEE is an invasive diagnostic tool, it hinders the comfort of the patient and causes nausea, gag reflex, dyspnoea, and emotional distress. Generally, TEE is performed in cardiology departments undertopical anaesthesia. Most patients cannot tolerate the introduction of the probe under topical anaesthesia; they feel sick during the procedure. As topical anaesthesia cannot totally eliminate gag reflex, a more effective and deeper sedation might be necessary for those patients who cannot tolerate the procedure $[1,2]$. Before pharyngeal intubation, for medical sedation purposes mild sedation studies were performed with a mild and short acting sedative and anxiolytic by using midazolam, which is a benzodiazepine. Propofol vs. midazolam and midazolam vs. remifentanil were compared to see mild and deep

\section{Address for correspondence:}

Dr Yuksel Dogan, Department of Cardiology, Bahçeşehir Medical University, Fatih Medical Park Hospital, Istanbul, Turkey, e-mail: yukseldogan@hotmail.com Received: 01.03.2015 Accepted: 03.08.2015 Available as AoP: 27.11.2015

Kardiologia Polska Copyright (C) Polskie Towarzystwo Kardiologiczne 2016 
sedation [3-5]. Hypnotic sedation has been shown to decrease postoperative stay, use of analgesics, pain and anxiety, and nausea-vomiting in breast biopsy, general surgery, open heart surgery, and plastic surgery [6-9].

At the same time, during the treatment of non-cardiac chest pain, the frequency of pain decreases; during percutaneous transluminal coronary angioplasty, the increase in cardiac sympathetic activity can be decreased with hypnotic sedation [10].

Heart rate variability (HRV) analysis evaluates the condition of the autonomic nervous system responsible for regulating cardiac activity and cardiac health in general. Thus, HRV is used to evaluate the sympathetic and parasympathetic modulation of the heart rate (HR) [11]. There are limited number of studies on HRV variability during TEE, which are both under medical and hypnotic sedation. The aim of our study is to see the effects of sedation with midazolam and hypnotherapy on HRV.

\section{METHODS \\ Patients}

Seventy-six patients (37 male and 39 female) at 18-83 years of age, who had an indication for TEE confirmed by our Cardiology Unit during October-December 2010 were included in our study. The indications for TEE were as follows: 28 of them were atrial septal defect, 14 were patent foramen ovale, 11 were bicuspid aortic valve, six were mitral valve prolapse, 10 were valvuloplasty, and seven were hypertrophic cardiomyopathy. There were no differences between groups regarding the indications. Patients under 18 years of age, those with heart failure, ventricular arrhythmia, complex congenital heart conditions, or obstructive lung diseases, those who could not cooperate during TEE, those who using benzodiazepines, antidepressants, and antipsychotics, or medications influencing the $\mathrm{HR}$, and those with thyroid conditions were excluded from the study.

All of the patients who were to participate in the study signed informed consent forms and the approval of the hospital Ethics Committee was obtained (the name of the ethics committee: Bakırkoy Dr. Sadı Konuk Hospıtal Ethics Committee, number: 9-7). The patients were randomised into three groups. Group T had 26 patients who only received topical anaesthesia with $1 \%$ lidocaine, Group D included 23 patients receiving midazolam, and Group $\mathrm{H}$ included 27 patients undergoing hypnosis. All the patients were in sinus rhythm. Before the procedure, IV access was established. They were monitored with non-invasive monitor throughout the procedure for $\mathrm{HR}$, rhythm electrocardiography (ECG), and $\mathrm{O}_{2}$ saturation. Blood pressure measurements were taken from the right arm every 3-5 min. The monitoring of these parameters started before the patient swallowed the TEE probe and was concluded after the probe was retrieved. Emergency resuscitation equipment and medications were kept ready throughout the procedure. Rhythm Holter monitor was placed before insertion of the probe, and the Holter recording was stopped after the retrieval of the probe. Following an $8 \mathrm{~h}$ fasting, TEE was performed to patients on left decubitus position by a cardiologist using Vivid S5, General Electric, United States. It was well tolerated, with no complications.

\section{Sedation}

Group $\mathrm{T}$ and the other two study groups received local anaesthesia to the oropharynx region with two puffs of $1 \%$ lidocaine spray. In Group D, before insertion of the probe, the patients were sedated with midazolam (Dormicum $1 \mathrm{mg} / \mathrm{mL}$ ampoules, Roche) at a dose of $0.05 \mathrm{mg} / \mathrm{kg}$ IV (to achieve a Ramsay Sedation Score [RSS] of 2-3). If needed, additional IV doses $(0.005 \mathrm{mg} / \mathrm{kg})$ were given during the procedure. No any other pharmacotherapy was used in any of the groups. The patients were kept under observation for 30-45 min after the procedure. Their haemodynamic and respiratory parameters were monitored.

\section{Hypnosis}

Hypnosis was performed by the same anaesthesiologist according to indirect Erickson's method [12]. A first hypnotic induction was carried out the day before the procedure. The hypnotic state was described to the patient as a state of mental focalisation on a pleasant life experience. The word "hypnosis" was intentionally not used, in order to avoid creating a positive or negative bias based on preconceived notions, instead they were told that they were taken under sessions of "encouragement" and "mental preparation" for the procedure. The next day, $15 \mathrm{~min}$ before the procedure, a new induction was performed and hypnosis was deepened. Every effort was made to produce a state of hypnosis, in which only ideas of relaxation and wellness were suggested to the patients during the procedure.

\section{Analysis of HRV parameters}

All the patients had Holter monitor on before swallowing the probe, and the Holter recording was terminated after the retrieval of the probe. Recordings were taken for 12-15 min on average. Holter ECGs were analysed using the CustoMed Holter system. The authors, blinded to the diagnosis of the patients, conducted the analyses of Holter ECGs. The HRV analysis was assessed over a period and was performed in time domains and frequency domains according to European Society of Cardiology/North American Society of Pacing and Electrophysiology guidelines. The following time domain parameters were calculated: mean of all normal RR intervals (mean RR); standard deviations of all NN intervals (SDNN); standard deviation of the averages of $\mathrm{NN}$ intervals in all 5-min segments of the entire recording (SDANN); the square root of 
Table 1. The evaluation of the groups based on demographic features

\begin{tabular}{|lcccc|} 
& Group D $(\mathbf{n}=\mathbf{2 3})$ & Group T $(\mathbf{n}=\mathbf{2 6})$ & Group H (n = 27) & P \\
\hline Age & $34.48 \pm 13.22$ & $37.88 \pm 19.15$ & $38.92 \pm 9.23$ & $0.535^{+}$ \\
Male & $11(47.8 \%)$ & $15(57.7 \%)$ & $11(40.7 \%)$ & $0.485^{++}$ \\
Female & $12(52.2 \%)$ & $11(42.3 \%)$ & $16(59.3 \%)$ & \\
\hline
\end{tabular}

${ }^{+}$One-way ANOVA test; ${ }^{++}$Chi-square test

Table 2. Systolic blood pressure (SAP) according to groups (in $\mathrm{mm} \mathrm{Hg}$ )

\begin{tabular}{|lcccc|}
\hline SAP & Group D $(\mathbf{n}=\mathbf{2 3})$ & Group T $(\mathbf{n}=\mathbf{2 6})$ & Group H $(\mathbf{n}=\mathbf{2 7})$ & $\mathbf{P}^{+}$ \\
\hline Baseline & $120.78 \pm 13.11$ & $132.92 \pm 25.80$ & $124.56 \pm 18.46$ & 0.073 \\
$1 \mathrm{~min}$ & $135.64 \pm 21.61$ & $151.04 \pm 28.79$ & $138.47 \pm 22.26$ & 0.055 \\
$3 \mathrm{~min}$ & $127.71 \pm 16.84$ & $142.50 \pm 26.66$ & $132.68 \pm 24.21$ & 0.061 \\
$5 \mathrm{~min}$ & $124.14 \pm 15.38$ & $137.34 \pm 26.25$ & $130.53 \pm 15.06$ & $0.047^{*}$ \\
$10 \mathrm{~min}$ & $124.32 \pm 15.49$ & $138.34 \pm 25.62$ & $127.47 \pm 18.85$ & $0.033^{*}$ \\
$0-1 \min \left(\mathrm{p}^{++}\right)$ & $0.001^{* *}$ & $0.001^{* *}$ & $0.001^{* *}$ & \\
$0-3 \min \left(\mathrm{p}^{++}\right)$ & $0.038^{*}$ & $0.004^{* *}$ & $0.002^{* *}$ & \\
$0-5 \min \left(\mathrm{p}^{++}\right)$ & 0.193 & 0.177 & $0.005^{* *}$ & \\
$0-10 \min \left(\mathrm{p}^{++}\right)$ & 0.236 & 0.084 & 0.269 & \\
\hline
\end{tabular}

+One-way ANOVA test; ${ }^{++}$Paired sample $t$ test; ${ }^{*} p<0.05 ;{ }^{* *} p<0.01$

the mean of the sum of the squares of differences between adjacent NN intervals (rMSSD); and the number of pairs of adjacent $\mathrm{NN}$ intervals differing by more than 50 ms divided by the total number of all NN intervals (pNN50). Spectral analysis of HRV included total power, which represents the variability of the entire signal and is obtained by summing powers of each frequency band, high-frequency (HF) component $(0.15-0.40 \mathrm{~Hz}$ ): low frequency (LF) component (0.04-0.15 Hz). The low-frequency power/high-frequency power (LF/HF) was calculated in all subjects.

\section{Statistical analysis}

For statistical analyses NCSS (Number Cruncher Statistical System) 2007 and PASS 2008 Statistical Software (Utah, United States) programmes were used. When the study data was evaluated, in addition to descriptive statistical methods (mean, standard deviation [SD]), oneway ANOVA test was used for the comparisons of quantitative data and intergroup comparisons of parameters with a normal distribution. For intergroup comparisons of parameters that did not have a normal distribution, Kruskal-Wallis test was used; Mann-Whitney $U$ test was used for the identification of the group that was different. Chi-square test was used for the comparisons of qualitative data. The statistical significance level was $p<0.05$. We performed power analysis. In conclusion, according to mean HR measurement we determined the difference as 8.5 between groups (delta) and as SD 10, the sampling number of groups was determined as $\mathrm{n}=22$ for $80 \%$ power and $\alpha=0.05$.

\section{RESULTS}

The study was performed on 76 patients. There were $37(48.7 \%)$ male and 39 (51.3\%) female patients. The age range of the patients changed between 18 and 83 years with a mean of $37.22 \pm 14.37$ years. The patients were analysed under three groups as " $\mathrm{D}$ " $(\mathrm{n}=23)$, " $\mathrm{T}$ " $(\mathrm{n}=26)$, and " $\mathrm{H}$ " $(n=27)$. There was no statistically significant difference between the mean ages and gender distributions of the groups ( $p>0.05$; Table 1). All of the TEE procedures were performed by the same cardiologist, and there were no complications related to the procedure in any of the groups.

Based on the means of systolic arterial pressure (SAP) measurements at the beginning and at $1 \mathrm{~min}$ and $3 \mathrm{~min}$, there was no statistically significant difference among the groups ( $p>0.05$ ); however, the mean SAP of Group D at 5 min and 10 min was significantly lower compared to the other two groups ( $p<0.05$; Table 2). Means of diastolic arterial pressure (DAP) at the baseline and at 1, 3, 5, and 10 min did not differ significantly among the groups ( $p>0.05)$; however, Group D had lower levels compared to other groups. In Group D; compared to peripheral $\mathrm{O}_{2}$ saturation $\left(\mathrm{SpO}_{2}\right)$ measurements at the beginning, the decreases seen in mean $\mathrm{SpO}_{2}$ levels at $1,3,5$, and 10 min were significant ( $p<0.01$ ), but this was not the case for the other groups (Table 3).

Maximum HR and mean HR were lower in the hypnosis group compared to the two other groups. However, means of maximum HR, mean $H R$, and minimal HR did not differ significantly among the groups $(p>0.05)$. The means of SDNN of the HRV time domain parameters and 
Table 3. Evaluation of the peripheral $\mathrm{O}_{2}$ saturation $\left(\mathrm{SpO}_{2}\right)$ of the groups

\begin{tabular}{|c|c|c|c|c|}
\hline $\mathrm{SpO}_{2}[\%]$ & Group D $(n=23)$ & Group T $(n=26)$ & Group H $(n=27)$ & $\mathbf{P}^{+}$ \\
\hline Baseline & $97.25 \pm 1.62$ & $97.19 \pm 2.78$ & $96.97 \pm 1.89$ & 0.863 \\
\hline $1 \mathrm{~min}$ & $95.78 \pm 2.63$ & $96.65 \pm 3.58$ & $96.87 \pm 1.70$ & 0.268 \\
\hline $3 \min$ & $95.50 \pm 2.38$ & $96.54 \pm 3.14$ & $96.62 \pm 1.91$ & 0.170 \\
\hline $5 \min$ & $95.78 \pm 2.21$ & $96.50 \pm 3.16$ & $96.72 \pm 2.26$ & 0.351 \\
\hline $10 \min$ & $96.00 \pm 1.74$ & $96.54 \pm 2.71$ & $96.84 \pm 1.93$ & 0.316 \\
\hline $0-1 \min \left(p^{++}\right)$ & $0.001 *$ & 0.143 & 0.720 & \\
\hline $0-3 \min \left(p^{++}\right)$ & 0.001 * & 0.094 & 0.276 & \\
\hline $0-5 \min \left(\mathrm{p}^{++}\right)$ & 0.001 * & 0.074 & 0.408 & \\
\hline $0-10 \min \left(p^{++}\right)$ & 0.001 * & 0.091 & 0.625 & \\
\hline
\end{tabular}

+One-way ANOVA test; ++Paired sample t test; ${ }^{*} p<0.01$

Table 4. Evaluation of the Holter recordings of the groups

\begin{tabular}{|c|c|c|c|c|}
\hline & Group D $(n=23)$ & Group T $(n=26)$ & Group H $(n=27)$ & $\mathbf{P}^{+}$ \\
\hline Max. HR & $110.95 \pm 19.60$ & $108.43 \pm 22.99$ & $105.54 \pm 18.98$ & 0.680 \\
\hline Mean HR & $92.39 \pm 12.40$ & $90.69 \pm 14.88$ & $87.89 \pm 13.11$ & 0.494 \\
\hline Min. HR & $81.48 \pm 13.57$ & $79.96 \pm 15.88$ & $83.29 \pm 12.02$ & 0.684 \\
\hline $\mathrm{SPC}^{+}$ & $0.56 \pm 1.20(0)$ & $6.19 \pm 21.68(0)$ & $3.52 \pm 13.61(0)$ & 0.308 \\
\hline $\mathrm{VPC}^{+}$ & $9.35 \pm 31.63(1)$ & $19.61 \pm 83.88(1)$ & $5.15 \pm 11.77(1)$ & 0.907 \\
\hline \multicolumn{5}{|c|}{ HRV parameters } \\
\hline \multicolumn{5}{|l|}{ Time-domain } \\
\hline SDNN [msn] & $83.22 \pm 31.77$ & $85.01 \pm 42.70$ & $97.25 \pm 42.25$ & 0.386 \\
\hline SDANN [msn] & $32.77 \pm 24.50$ & $35.44 \pm 26.82$ & $43.69 \pm 23.07$ & 0.300 \\
\hline pNN50 [\%] & $6.29 \pm 8.82(3.3)$ & $17.93 \pm 20.26(10.6)$ & $19.45 \pm 22.42(15.9)$ & 0.001 * \\
\hline RMSSD [msn] & $51.80 \pm 41.39(40.8)$ & $69.82 \pm 45.02(52.6)$ & $94.88 \pm 87.20(78.8)$ & $0.006^{*}$ \\
\hline \multicolumn{5}{|c|}{ Frequency-domain } \\
\hline $\mathrm{SDLF}^{+}[\mathrm{nu}]$ & $4.18 \pm 2.511(3.6)$ & $5.04 \pm 5.33(3.0)$ & $3.09 \pm 3.88(2.4)$ & 0.124 \\
\hline $\mathrm{SDHF}^{+}[\mathrm{nu}]$ & $1.34 \pm 1.26(0.9)$ & $1.12 \pm 0.95(0.7)$ & $2.32 \pm 4.42(0.8)$ & 0.726 \\
\hline SDLF/SDHF ${ }^{+}$ & $4.61 \pm 3.62(3.1)$ & $8.93 \pm 14.92(2.7)$ & $2.01 \pm 1.27(1.6)$ & $0.001 *$ \\
\hline
\end{tabular}

One-way ANOVA test; ${ }^{+}$Kruskal-Wallis test; ${ }^{*} \mathrm{p}<0.01$; max. $\mathrm{HR}$ - maximum heart rate; mean $\mathrm{HR}$ - mean heart rate; min. HR - minimum heart rate; SPC — supraventricular premature contraction; VPC — ventricular premature contraction; HRV — heart rate variability; SDNN — standard deviations of all NN intervals; SDANN - standard deviation of the averages of NN intervals in all 5-min segments of the entire recording; RMSSD - the square root of the mean of the sum of the squares of differences between adjacent NN intervals; pNN50 - the number of pairs of adjacent NN intervals differing by more than 50 ms divided by the total number of all NN intervals; LF (SDLF) — power in low frequency range with its standard deviations and in normalised units; HF (SDHF) - power in high frequency range with its standard deviations and normalised units

SDANN levels did not differ significantly among the groups $(p>0.05)$; however, there were statistically significant differences among the $\mathrm{pNN} 50$ levels of the groups $(\mathrm{p}<0.01)$. pNN50 levels of Group D were significantly lower than those of Group T ( $p=0.002)$ and Group H $(p=0.001)$ $(p<0.01)$. There was no significant difference between the pNN50 levels of Groups $\mathrm{T}$ and $\mathrm{H}(\mathrm{p}>0.05)$. There was a significant difference between the RMSSD levels of the groups $(p<0.01)$. RMSSD levels of Group D were significantly lower than those of Groups $\mathrm{T}(\mathrm{p}=0.044)$ and $\mathrm{H}$ $(p=0.001)(p<0.05, p<0.01)$. There was no significant difference between the RMSSD levels of Groups $\mathrm{T}$ and $\mathrm{H}$ ( $p>0.05$; Table 4).

Of the HRV frequency domain parameters, means of LF were lowest in Group $\mathrm{H}$, but there was no significant difference among the groups as concerns this parameter $(p>0.05)$. Similarly, means of HF were highest in Group $\mathrm{H}$, but there was no statistically significant difference among the groups $(p>0.05)$. LF/HF levels differed significantly among the groups ( $p<0.01)$. LF/HF levels of Group $\mathrm{H}$ was significantly lower than Groups D $(p=0.001)$ and T $(p=0.001)$. There was no significant difference between LF/HF levels of Groups T 
and D ( $p>0.05)$. Mean supraventricular premature contraction and mean ventricular premature contraction levels of the groups did not differ significantly ( $p>0.05$; Table 4$)$.

\section{DISCUSSION}

While causing emotional stress and inducing gag reflex, TEE also causes changes in the $\mathrm{HR}$, blood pressure, and $\mathrm{O}_{2}$, saturation $[1,4]$. Stress response is a complex action-reaction response resulting from several exogenous and endogenous stimuli. Stress response is sometimes handled through the sympathetic nervous system, resulting in increases in the HR and blood pressure of the individual concerned [13].

In our study, maximum and mean HR was found to be highest in Group D using midazolam and lowest in hypnosis group; however, there was no statistically significant difference among the three groups $(p=0.05)$. In their studies, Blondheim et al. [3] found that when the group sedated with midazolam was compared to the topical anaesthesia group, there was a significant increase in the HR. Tachycardia during TEE results from stress. Midazolam being an anxiolytic, we anticipate a decrease in tachycardia with its use; however, its showing an opposite effect can be evaluated as a reflex increase resulting from its systemic vascular resistance reducing potential [3]. On the other hand, hypnotic intervention has been shown to yield variable catecholamine and cortisol responses [14]. The study dramatically demonstrated that individual variability was closely related to hypnotic intervention, and that HR was decreased with deep relaxation suggestion. As anxiety rates decreased, catecholamine levels returned to normal. In the hypnosis group, there was no significant decrease in blood pressure and $\mathrm{O}_{2}$ saturation. Although not statistically significant, blood pressure levels of the midazolam group were lower compared to other groups, and $\mathrm{O}_{2}$ saturation was also decreased significantly $(p<0.01)$. This can be explained through the depressive effects of midazolam on blood pressure and $\mathrm{O}_{2}$ saturation. However, hypnotic sedation did not show a significant depression on haemodynamics and ventilation $[3,15]$

Heart rate variability reflects the effects of autonomic nervous system on sinus node activity. HRV is a complex measurement of HR modulation encompassing sympathetic effects, parasympathetic effects, and interactions thereof. In the time-domain analysis, SDNN represents a general measurement of autonomic nervous system balance. SDNN is related to the total power. SDANN reflects long-term components of HRV mediated by both sympathetic and parasympathetic influences, while RMSSD reflects short-term components of HRV mediated by parasympathetic respiratory variations [16]. pNN50 is primarily an index of parasympathetic tone. In our study, in the hypnosis group, SDNN and SDANN showed increases compared to the two other groups despite not reaching the level of statistical significance $(p=0.386$, $p=0.300$, respectively); pNN50 and RMSSD had statisti- cally significant increases in the hypnosis group $(p=0.001$, $p=0.006)$. Increases in RMSSD and pNN50 parameters in the hypnosis group indicate increased parasympathetic and decreased sympathetic nervous system activity. This demonstrates us that sedation with midazolam does not decrease sympathetic activity. In the frequency domain analysis, LF represents mainly the sympathetic and the HF reflects mainly the parasympathetic nervous system. Frequency domain methods should be preferred to the time domain methods when investigating short-term recordings [17]. In our study group, in the frequency domain analysis, LF parameter was lower in the hypnosis group compared to the midazolam and topical groups whereas HF was higher but not significant. $\mathrm{LF} / \mathrm{HF}$ rate was significantly lower in the hypnosis group compared to other two groups. In their study, Aubert et al. [18] found that in healthy individuals LF levels were decreased in the hypnosis group while HF was increased and LF/HF rate was decreased. DeBenedittis et al. [19] found similar results in healthy individuals undergoing hypnosis. Yuksel et al. [20] demonstrated that in women HRV decreased during hypnosis. Baglini et al. [10] demonstrated that the increase in the sympathetic activity during transluminal coronary angioplasty could be decreased with hypnosis but not with benzodiazepines. Our findings are in parallel with these studies, and our study demonstrates that hypnosis affects HRV, shifting the balance of the sympathovagal interaction toward an enhanced parasympathetic activity, concomitant with a reduction of the sympathetic tone. Hypnosis decreases the central signalling of nociceptive stimuli at different levels [21]; moreover, cortical and subcortical correlates of autonomic activation have been found. In particular, inhibition of serotoninergic neurons during animal hypnosis have been demonstrated, and this kind of neuron, whose activation accompanies sympathoexcitation, has been found in spinal cord and brainstem regions known to be involved in autonomic regulation [22]. Winn et al. [23] demonstrated that midazolam showed dominant sympathetic effects during the sedation period. The main effects of benzodiazepines are sedation, decreased anxiety, anterograde amnesia, and centrally mediated muscle relaxation. In addition to their actions on the central nervous system, benzodiazepines have a dose-dependent ventilatory depressant effect and they also cause a modest reduction in arterial blood pressure and an increase in the HR as a result of a decrease in systemic vascular resistance. These drugs are known to act predominantly on cortical prefrontal areas and can inhibit sympathetic drive only by weakening emotional and perceptive mechanisms. Tsugayasu et al. [24] demonstrated that midazolam more effectively suppresses sympathetic activations and reduces stress feelings during mental arithmetic task. Ristikankare et al. [25] found that gastroscopy induces a shift towards dominance of the sympathetic modulation of the heart, and sympathetic activation was decreased in the midazolam treated patients. 


\section{CONCLUSIONS}

In conclusion, in TEE patients autonomic tone was significantly modified with hypnosis but not with midazolam sedation. Hypnotic sedation achieves this by increasing parasympathetic activity, decreasing sympathetic activity, and changing the balance of sympathovagal interaction.

\section{Conflict of interest: none declared}

\section{References}

1. Ferson D, Thakar D, Swafford J et al: Use of deep intravenous sedation with propofol and the laryngeal mask airway during transesophageal echocardiography. JCardiothorac Vasc Anesth, 2003; 17: 443-446. doi:10.1016/S1053-0770(03)00147-2.

2. Renna M, Chung R, Li W et al. Remifentanil plus low-dose midazolam for outpatient sedation in transesophageal echocardiography. Int J Cardiol, 2009; 136: 325-329. doi: 10.1016/j. ijcard.2008.05.034.

3. Blondheim DS, Levi D, Marmor AT. Mild sedation before transesophageal echocardiography induces significant hemodynamic and respiratory depression. Echocardiography, 2004; 21: 241-245. doi: 10.1111/j.0742-2822.2004.03075.x.

4. Aeschbacher BC, Portner M, Fluri M et al. Midazolam premedication improves tolerance of transesophageal echocardiography. Am J Cardiol, 1998; 81: 1022-1026. doi:10.1016/S00029149(98)00083-6.

5. Sutaria N, Northridge D, Denvir M. A survey of sedation and monitoring practices during transoesophageal echocardiography in the UK: are recommended guidelines being followed? Heart, 2000; 84 (suppl. 2): II19. doi:10.1136/heart.84.suppl_2. ii19.

6. Montgomery GH, Weltz CR, Seltz M et al. Brief presurgery hypnosis reduces distress and pain in excisional breast biopsy patients. Int J Clin Exp Hypn, 2002; 50: 17-32. doi: 10.1080/00207140208410088.

7. Meurisse M, Hamoir E, Defechereux T et al. Bilateral neck exploration under hypnosedation: a new standard of care in primary hyperparathyroidism? Ann Surg, 1999; 229: 401-408. doi: 10.1097/00000658-199903000-00014.

8. Hart RR. The influence of a taped hypnotic induction treatment procedure on the recovery of surgery patients. Int J Clin Exp Hyp, 1980; 28: 324-332. doi: 10.1080/00207148008409861.

9. Faymonville ME, Fissette J, Mambourg PH et al. Hypnosis as adjunct therapy in conscious sedation for plastic surgery. Reg Anesthes, 1995; 20: 145-151.

10. Baglini R, Sesana M, Capuano C et al. Effect of hypnotic sedation during percutaneous transluminal coronary angioplasty on myocardial ischemia and cardiac sympatheticdrive. Am JCardiol, 2004; 93: 1035-1038. doi: 10.1016/j.amjcard.2003.12.058.

11. Kaya EB, Okutucu S, Aksoy $\mathrm{H}$ et al. Evaluation of cardiac autonomic functions in patients with ankylosing spondylitis via heart rate recovery and heart rate variability. Clin Res Cardiol, 2010; 99: 803-808. doi: 10.1007/s00392-010-0187-x.

12. Fourie DP. Indirect suggestion in hypnosis:theoretical and experimental issues. Psychol Rep, 1997; 80: 1255-1266. doi: 10.2466/pr0.1997.80.3c.1255.

13. Sturgis LM, Coe WC. Physiological responsiveness during hypnosis. Int J Clin Exp Hypn, 1990; 38: 196-207. doi: 10.1080/00207149008414518.

14. Bandura A, Taylor CB, Williams SL et al. Catecholamine secretion as a function of perceived coping self-efficacy. J Consult Clin Psychol, 1985; 53: 406-414. doi:10.1037/0022-006X.53.3.406.

15. Fleischer DE, Goldstein SA. Transesophageal echocardiography: what the gastroenterologist thinks the cardiologist should know about endoscopy. J Am Soc Echocardiography, 1990; 3: 428-434. doi:10.1016/S0894-7317(14)80146-6.

16. Munk PS, Butt N, Larsen AI. High-intensity interval exercise training improves heart rate variability in patients following percutaneous coronary intervention for angina pectoris. Int. J Cardiol, 2010; 145: 312-314. doi: 10.1016/j.ijcard.2009.11.015.

17. Task Force of the European Society of Cardiology and the North American Society of Pacing and Electrophysiology. Heart rate variability: standards of measurement, physiological interpretation and clinical use. Circulation, 1996; 93: 1043-1065. doi: 10.1161/01.CIR.93.5.1043.

18. Aubert AE, Verheyden B, Beckers F et al. Cardiac autonomic regulation under hypnosis assessed by heart rate variability: spectral analysis and fractal complexity. Neuropsychobiology, 2009; 60: 104-112. doi: 10.1159/000239686.

19. DeBenedittis G, Cigada M, Bianchi A et al. Autonomic changes during hypnosis: a heart rate variability power spectrum analysis as a marker of sympatho-vagal balance. Int J Clin Exp Hypn, 1994; 42: 140-152. doi:10.1080/00207149408409347.

20. Yüksel R, Ozcan O, Dane S. The effects of hypnosis on heart rate variability. Int J Clin Exp Hypn, 2013; 61: 162-171. doi: 10.1080/00207144.2013.753826.

21. Faymonville ME, Laureys S, Degueldre C et al. Neural mechanisms of antinociceptive effects of hypnosis. Anesthesiology, 2000; 92: 1257-1267. doi: 10.1097/000000542-200005000-00013.

22. Hisamitsu T, Fujishita M, Asamoto S et al. Serotoninergic neurons in the brainstem modulate animal hypnosis. Brain Res Bull, 1992; 29: 141-145. doi: 10.1016/0361-9230(92)90019-T.

23. Win NN, Fukayama H, Kohase $\mathrm{H}$ et al. The different effects of intravenous propofol and midazolam sedation on hemodynamic and heart rate variability. Anesth Analg, 2005; 101: 97-102. doi: 10.1213/01.ANE.0000156204.89879.5C.

24. Tsugayasu R, Handa T, Kaneko Y et al. Midazolam more effectively suppresses sympathetic activations and reduces stress feelings during mental arithmetic task than propofol. J Oral Maxillofac Surg, 2010; 68: 590-596. doi: 10.1016/j.joms.2009.07.034.

25. Ristikankare M, Julkunen R, Heikkinen M et al. Cardiac autonomic regulation during gastroscopy. Dig Liver Dis, 2009; 41: 648-652. doi: 10.1016/j.dld.2009.01.008.

Cite this article as: Dogan Y, Eren GA, Tulubas E et al. The effect of sedation during transoesophageal echocardiography on heart rate variability: a comparison of hypnotic sedation with medical sedation. Kardiol Pol, 2016; 74, 591-597. doi: 10.5603/KP.a2015.0237. 


\title{
Wpływ sedacji w trakcie echokardiografii przezprzełykowej na zmienność rytmu serca: porównanie sedacji za pomocą hipnozy z sedacją farmakologiczną
}

\author{
Yuksel Dogan' ${ }^{1}$, Gulay A. Eren², Evrım Tulubas², Vecihi Oduncu' ${ }^{1}$, Alparslan Sahin ${ }^{1}$, Serkan Ciftci ${ }^{1}$ \\ 1'Department of Cardiology, Bahçeşehir Medical University, Fatih Medical Park Hospital, Istanbul, Turcja \\ ${ }^{2}$ Department of Anaesthesiology and Intensive Care, Bakirkoy Dr. Sadi Konuk Education and Research Hospital, Istanbul, Turcja
}

\section{Streszczenie}

Wstęp: Nie ma idealnej metody sedacji, która mogłaby być stosowana w trakcie echokardiografii przezprzełykowej (TEE), a dane dotyczące wpływu dostępnych metod sedacji na zmienność rytmu serca (HRV) są ograniczone.

Cel: Badanie przeprowadzono w celu porównania wpływu na HRV sedacji uzyskanej metodą hipnoterapii i sedacji farmakologicznej z zastosowaniem midazolamu.

Metody: Do badania włączono 76 chorych ze wskazaniami do wykonania TEE, w wieku 18-83 lat. Grupa T obejmowała 26 chorych, u których badanie wykonano po zastosowaniu miejscowego znieczulenia gardła, grupa D - 23 chorych, którym podano midazolam, a grupa $\mathrm{H}-27$ chorych, których poddano hipnozie. U wszystkich pacjentów zapewniono dostęp dożylny. Przez cały czas trwania badania monitorowano częstość rytmu serca, zapis elektrokardiograficzny i saturację tlenem krwi obwodowej metodą nieinwazyjną; pomiary ciśnienia tętniczego wykonywano co 3 minuty. U wszystkich pacjentów uzyskano zapis rytmu serca metodą Holtera i przeprowadzono TEE.

Wyniki: Porównując parametry HRV uzyskane w trzech grupach, stwierdzono, że w grupie poddanej hipnozie wartości pNN50 i RMSSD były istotnie wyższe niż w grupach D i T $(p<0,05)$. Na podstawie oceny parametrów analizy częstotliwościowej nie wykazano istotnych różnic między osobami poddanymi hipnozie, u których stwierdzono zmniejszenie mocy widma w zakresie niskich częstotliwości (LF) i zwiększenie w zakresie wysokich częstotliwości (HF) ( $p>0,05)$. Jednak zaobserwowano statystycznie istotną $(p<0,05)$ redukcję współczynnika LF/HF w porównaniu z grupą, której podano midazolam.

Wnioski: W przeciwieństwie do standardowej metody sedacji u chorych poddanych TEE stosowanie hipnozy wiązało się z istotną zmianą napięcia autonomicznego układu nerwowego serca. Sedacja za pomocą hipnozy powodowała zwiększenie aktywności przywspółczulnej, zmniejszenie aktywności współczulnej i zmianę balansu interakcji między układem współczulnym a przywspółczulnym (nerw błędny).

Słowa kluczowe: echokardiografia przezprzełykowa, zmienność rytmu serca, sedacja za pomocą hipnozy, midazolam

Kardiol Pol 2016; 74, 6: 591-597 